\title{
SPHK1 wt Allele
}

National Cancer Institute

\section{Source}

National Cancer Institute. SPHK1 wt Allele. NCI Thesaurus. Code C92512.

Human SPHK1 wild-type allele is located in the vicinity of $17 q 25.2$ and is approximately 3 $\mathrm{kb}$ in length. This allele, which encodes sphing osine kinase 1 protein, is involved in the modulation of sphing osine phosphorylation and signaling. 